nical for you to claim ropriate to offer your cequest it. Depending with your work may Trust your instincts, rticles can be an ex6

ake certain your arti. Journals may receive enty slots. Never ask ubmission, but to the hical about asking a sion is reviewed.

apply when you are apply when you are are carefully crafted rt to rule in your clidraft an article. The your submission, the ss of placing it.

\title{
GLIMPSES OF MARSHALL IN THE MILITARY
}

\author{
Kevin C. Walsh *
}

Before President John Adams appointed him as Chief Justice of the United States in 1801, John Marshall was a soldier, a state legislator, a federal legislator, an envoy to France, and the Secretary of State. ${ }^{1} \mathrm{He}$ also maintained a thriving practice in Virginia and federal courts, occasionally teaming up with political rival and personal friend Patrick Henry. Forty-five years old at the time of his appointment to the Supreme Court, Marshall had been serving his state and his country for a quarter century before he took judicial office.

Marshall is an exemplar of professional excellence for all law. yers and judges. But one looking for life lessons in the law from the life of John Marshall should not neglect his time as a soldier, before he became a lawyer.

"From my infancy I was destined for the bar," Marshall would write later in his life, "but the contest between the mother country \& her colonies drew me from my studies \& my Father from the superintendence of them; \& in September 1775 , I entered into the service as a subaltern." Beginning in a Fauquier County militia, continuing through with the Culpeper Minutemen, and then serving as an officer in the Continental Army, John Marshall spent the better part of five years in active military service. This

\footnotetext{
* Professor of Law, University of Richmond School of Law. This essay is adapted from a CLE presentation on legal professionalism co-sponsored by the James Madison Chapter of Phi Delta Phi, the Moot Court Board, the Trial Advocacy Board, and the John Marshall Foundation. The author thanks those organizations for their sponsorship of that event dedicated to the Great Chief Justice.

1. The best single-volume biographies of John Marshall published in the past two decades are JEAN EDWARD SMTH, JOHN MARSHALL: DEFINER OF A NATION (1996) and R. KENT NEWMYER, JOHN MARSHALl AND THE HEROIC AGE OF THE SUPREME COURT (2001).

2. Letter from John Marshall to Joseph Delaplaine (Mar. 22, 1818), in VIII THE PAPERS OF JOHN MARSHALL 187 (Charles F. Hobson, ed., 1995), http://rotunda.upress.virg inia.edu/founders/default.xqy?keys=dNML-chron-1810-1818-03-22-1.
} 
period, from the age of nineteen to twenty-four, formed Marshall's outlook in ways that rippled outward through his entire life.

It was in the Continental Army, Marshall later wrote, "associated with brave men from different states who were risking life and every thing valuable in a common cause believed by all to be most precious ... where I was confirmed in the habit of considering America as my country, and Congress as my government." Marshall himself and his later biographers have drawn a direct connection between his army experience and his political outlook. "My immediate entrance into the state legislature [after serving in the military]," Marshall wrote, "opened to my view the causes which had been chiefly instrumental in augmenting [the] sufferings [of the army], and the general tendency of state politics convinced me that no safe and permanent remedy could be found but in a more efficient and better organized general government." ${ }^{.5}$ Less appreciated than the link between Marshall's military experience and his political outlook, but no less important, is the link between Marshall the soldier and Marshall the lawyer. The influence of Marshall's military experience on his formation as a lawyer, however, was pervasive.

We have already seen how Marshall described the hostilities with "the mother country" as breaking off the studies he took under the direction of his father. But even before joining the Culpeper Minutemen in September 1775, Marshall had been training for the military to the exclusion of his legal studies. "About the time I entered my eighteenth year [in September 1773]," Marshall would later write,

the controversy between Great Britain and her colonies had assumed so serious an aspect as almost to monopolize the attention of the old and the young. I engaged in it with all the zeal and enthusiasm which belonged to my age; and devoted more time to learning the first rudiments of military exercise in an Independent company of the gentlemen of the county, to training a militia company in the

3. The most comprehensive account of John Marshall's time in the military is KEITH MARSHALL JONES III, "CONGRESS AS MY GOVERNMENT": CHIEF JUSTICE JOHN MARSHALL IN THE AMERICAN REVOLUTION (1775-1781) (2008).

4. "Autobiographical Sketch," Letter from John Marshall to Joseph Story (July 25, 1827), in XI The PAPERS OF JohN MARSHall 38 (Charles F. Hobson, ed., 2002), http://rot unda. upress.virginia.edu/founders/JNML-01-11-02-0017.

5. Id. 
$r$, formed Marshall's his entire life. ${ }^{3}$

later wrote, "associho were risking life believed by all to be he habit of consider. s my government." have drawn a direct his political outlook. ature [after serving my view the causes nenting [the] sufferof state politics cony could be found but neral government."5 hall's military expeaportant, is the link e lawyer. The influformation as a law-

cibed the hostilities studies he took unre joining the Cul11 had been training studies. "About the ember 1773]," Mar-

nies had assumed ttention of the old 1 and enthusiasm te to learning the ndent company of a company in the

ne in the military is KEITH USTICE JOHN MARSHALL IN neighbourhood, and to the political essays of the day, than to the classics or to Blackstone.

Marshall's only formal legal education-a few months of law lectures by George Wythe at the College of William and Mary-took place in early 1780, while he was still in the Continental Army, but on furlough. He received his law license, under the signature of then-Governor Thomas Jefferson, in August 1780. But Marshall could not begin his law practice at that time because the courts in Virginia were closed due to British forces.

When Marshall did begin his practice, his army experience was a boon for business. "My extensive acquaintance in the army was of great service to me," Marshall later wrote. "My numerous military friends, who were dispersed over the state, took great interest in my favour, and I was more successful than I had reason to expect."

Before commencing his private practice, and even before he was licensed as a lawyer, however, Marshall had already served as a legal professional of sorts in the military. In November 1777 , Marshall was appointed Deputy Judge Advocate General ("DJAG"). He served in that role for almost a year (until August 1778, it seems).

As a DJAG, Marshall would have assisted with court martials, transcribed the records of proceedings, and performed various ministerial and notarial functions. He would have had to possess detailed knowledge of military law and procedure. And he would have had to have a hardy physical constitution. For during the winter of 1777 into 1778, when Marshall served as DJAG, he was with General Washington's Main Army at Valley Forge.

One interested in qualities that contribute to excellence in the law might wonder why Marshall was tapped to be a DJAG despite his lack of formal legal training or experience. (This was highly unusual, as the JAG and most DJAGs had prior practice experience as lawyers.) From the accounts of his contemporaries, three qualities stand out: intelligence, judgment, and temperament.

6. Id. at 36 .

7. Id. at 37 .

8. Id.

9. For an account of Marshall's experiences and responsibilities as a DJAG, see JONES, supra note 3 , at $127-37$. 
His fellow officers would have seen Marshall's legal intelligence from his comportment in court martials that he had sat on as an officer. (The officers sitting on a court martial were the functional equivalent of judge and jury, and they relied on the JAG or DJAG for technical legal advice in addition to the facts of the case.) Intellectual horsepower would have been a necessary quality for a DJAG in a professional military like the Continental Army that followed the rules and procedures of the detailed military law set forth in the Articles of War.

Marshall's sound judgment-even at this young age-was widely remarked. According to one account,

all those, who intimately knew him, affirmed, that his capacity was held in such estimation by many of his brother officers, that in many disputes of a certain description he was constantly chosen arbiter; and that officers, irritated by differences or animated by debate, of ten submitted the contested points to his judgment, which being given in writing, and accompanied, as it commonly was, by sound reasons in support of his decision, obtained general acquiescence. ${ }^{10}$

Marshall's temper-even-keeled, content, unruffled-was perhaps the most conspicuously commented-on quality of his character. The shining value of this character trait emerges in clear relief when set against the bleak backdrop of the army encampment at Valley Forge. In the words of nineteenth-century chronicler Henry Howe, John Marshall

was one of that body of men, never surpassed in the history of the world, who, unpaid, unclothed, unfed, tracked the snows of Valley Forge with the blood of their footsteps in the rigorous winter of 1778 , and yet turned not their faces from their country in resentment, or from their enemies in fear.

This astounding endurance required cultivation and effort. It also took a certain kind of person not only to make it through, but also to carry others with them, as Marshall did for the men in his command. For in addition to serving as DJAG, Marshall was Acting Company Commander for his unit at Valley Forge. Here is Marshall's Valley Forge cabin mate, Philip Slaughter, describing Marshall's deportment during that severe and trying time:

He was the best-tempered man I ever knew. During his sufferings at Valley Forge, nothing discouraged, nothing disturbed him. If he had

10. Joseph Story, Chief Justice Marshall's Public Life and Services, 26 N. AM. REV. I, 8 (1828). On Story's authorship of this review, see NEWMYER, supra note 1 , at 469.

11. HENRY HOWE, HISTORICAL COLLECTIONS OF VIRGINIA 263 (1852). 
Il's legal intelligence he had sat on as an were the functional on the $\mathbb{I A G}$ or DJAG acts of the case.) Inessary quality for a tinental Army that iled military law set

is young age-was

it his capacity was cers, that in many ty chosen arbiter; ated by debate, of $t$, which being give vas, by sound reaquiescence. ${ }^{10}$

unruffled-was peruality of his characemerges in clear rearmy encampment -century chronicler

the history of the e snows of Valley us winter of 1778 , in resentment, or

ation and effort. It lake it through, but for the men in his Marshall was Actlley Forge. Here is aughter, describing trying time:

his sufferings at ed him. If he had

Services, 26 N. AM. REV, 1, ora note 1 , at 469 .

3 (1852). [only] bread to eat, it was just as well; if only meat, it made no difference. If any of the officers murmured at their deprivations, he would shame them by good-natured raillery, or encourage them by his own exuberance of spirits. He was an excellent companion, and idolized by the soldiers and his brother officers, whose gloomy hours were enlivened by his inexhaustible fund of anecdote.

Is it any surprise that Marshall's company had a higher proportion of men fit to serve than prevailed in the army as a whole? And is not this kind of success-gutting it out and emerging with men still fit to fight, sometimes by means as simple as daily good temper and a proto-Lincolnian penchant for anecdote-exactly what the military situation demanded?

$$
* \%
$$

We glimpse in these sketches of Marshall in the military some of the same qualities that carried him through the rest of his personal and professional life. While Marshall is often recognized and praised for his outwardly, obvious achievements, we should not ignore the internal excellences that contributed to them and constituted him. When we attend to those, we see a different kind of greatness than is more commonly recognized as such. We see virtue for the ages, worthy of emulation today.

12. Edgar Aldrich, John Marshall as a Soldier, in PRoceEdINGS OF THE BAR ASSOCIATION OF THE STATE OF NEW HAMPSHIRE at ITS CELEBRaTION OF JOHN MARSHaLl DAY 323, 331 (1901). In this version of the quotation from Slaughter's diary, I have substituted "only" bread for "no" bread, which is how the diary entry is more often quoted. See, e.g., Address of Mr. Justice Mitchell, in 1 JOHN MARSHALL: LIFE, CHARACTER AND JUDICIAL SERVICES 452,458 (John F. Dillon, ed., 1903). Unfortunately, the original diary appears no longer to be available. See PHILIP SLAUGHTER, A HISTORY OF ST. MARK'S PARISH, CULPEPER COUNTY, VIRGINIA 108 (1877) ("Capt. Slaughter kept a diary of his campaigns, which was lost in the wreck of so many fine libraries in the late war."). 